\title{
A WORD ABOUT THE CONTEXT
}

The world in which Carl Proffer and I met Joseph Brodsky is long gone-really known only to the children of the Cold War-so a few words about the context for this memoir are perhaps necessary for readers unfamiliar with how young Americans experienced that period.

The Cold War began as World War II was ending and military and civilian witnesses saw the Soviet Union's takeover of countries all along its borders. These countries would come to be called the captive or satellite nations, depending on who was speaking. The brutal assimilation of these countries led the United States into a number of wars in response-most notably in Korea and Vietnam - as well as to bloody interference in the politics of Central and South American countries. The Soviet justification for its own unacceptable actions was that their enormous country needed protection-in the form of borderlands-from their enemies; the American justification for its unacceptable actions was that Communism led to tyranny and that it must be stopped wherever it started. This is, of course, a very simplified explanation, but it will do to indicate the atmosphere of mutual suspicion between these two great atomic powers in the 1950s and 1960s. 


\section{viii Brodsky Among Us}

Russia had a presence in the everyday lives of young Americans in the 1950s and 1960s, and that presence had an emotion attached to it: fear. We hid under our desks during civil defense drills in school, and we knew why our parents were building bomb shelters. Bombs were in our dreams, and the Soviet Union was in our consciousness as a country that crushed revolts in both Hungary and Czechoslovakia. The leaders of the Soviet Union seemed unknowable and that led to a fear that they might attack us first out of paranoia.

As our generation came to adulthood, its other concern was the gradually increasing American involvement in Vietnam, a place where our cousins and brothers would go to fight in what became an incomprehensible war to stop Communism. A draft was in effect, something that makes the young pay attention to the nature of a given war. We paid attention and concluded that this war was not worth the price. Given this looming presence of the Soviet Union, one might presume that Carl and I made the decision to study Russian in the grand tradition of understanding your enemy; but oddly enough, that was not a conscious motivation for either of us: we came to Russian studies out of an interest in one of the world's great literatures. We came to this literature by different paths, but our reaction was the same. This literature-deep, rich, and powerful—was a revelation after French and English literature, which was what we knew. In the nineteenth century Pushkin, Gogol, Tolstoy, Dostoevsky, and Chekhov had somehow 
emerged from what was mostly an illiterate peasant country. What followed this golden age was Russia's tragic twentieth century, when war, revolution, civil war, and tyranny combined to almost destroy an entire culture. The miracle was that it did not entirely succeed. It was an intense literature, and we were intense people.

Even though Carl Ray Proffer was born in 1938 and I was born in 1944, and we grew up in different parts of the country, we shared one thing: there was nothing about our backgrounds that would have told you that we would have a life dedicated to Russian literature.

Carl Ray Proffer came from parents who had not finished high school, but who had done very well nonetheless. Carl went to the University of Michigan at Ann Arbor intending to be a basketball player or, if that didn't work out, a lawyer. In his first year he had to choose a foreign language to study; he looked at a board listing courses in different languages and saw the Russian alphabet for the first time. He looked at it and said to himself "What an interesting alphabet." He especially noticed the letter "ж," shaped like a butterfly, and it was this beautiful letter that led him to choose Russian, which in turn led him to classes in Russian literature. Carl, who had read so little literature of any kind up to this point, now encountered the writers of the golden age. This very intelligent man, who, with his exceptional memory and superior logic, should have been a lawyer, fell in love with Russian literature. This was a surprise 


\section{x Brodsky Among Us}

to everyone around him, and his family worried about what kind of career he could have in such an unpromising field. He decided to do his dissertation on Gogol.

In 1962 Carl took his first trip to the Soviet Union and did not have a particularly good time, since the few Russians he was allowed to meet were mostly monitors of foreigners. He did, however, manage to do a lot of traveling around the country and serious research on Gogol. At a young age he became an excellent teacher, translator, and scholar, publishing an enormous amount in a short time. His main subjects-and influenceswere Pushkin, Gogol, and Nabokov.

Unlike Carl, I came from a family of readers, although no one was particularly interested in foreign languages. My first Russian contact was with Dostoevsky, whose Crime and Punishment I read at the age of thirteen. I was quite aware that I could not really understand the novel, but I felt its force. When I was fifteen, my math teacher, who had learned Russian in the army, lent me a translation of Mayakovsky's poems, and I was impressed, especially by "The Backbone Flute." (I could never have conceived that I would later come to know Lily Brik, the woman who had inspired it.)

I majored in French and Russian and went to graduate school at Indiana University. In my first year of graduate school I read Bulgakov's The Master and Margarita and recognized immediately that this novel was going to be my scholarly focus. 
I met Carl Proffer for the first time that same year, 1966, at his notorious lecture on Lolita (sexual quotes from the novel, shocked émigré ladies, thrilled graduate students). He was a new professor at Indiana and was then working on his second book, Keys to Lolita. In the space of two years we fell in love, divorced our partners, and married each other.

In January 1969 we left Indiana on our way to Moscow and a scholarly exchange. We stopped in New York City on the way and had a series of crucial meetings in Manhattan bars. Gleb Struve, a famous émigré literary scholar, met us in the first bar and declared that we should abandon our trip because the Soviets had violently repressed the revolt in Czechoslovakia the previous year: it was immoral, in his view, to even visit the Soviet Union. But nothing could change our minds. We were tired of the polarities of the Cold War, we wanted to see the Soviet Union and decide for ourselves. We were not proud of our own country as it struggled with civil rights for African-Americans and bombed civilians in Cambodia and Vietnam, and this had the effect of making us question Cold War attitudes. We wanted to get to know the Soviet Union better and decide for ourselves.

On our own merits we would certainly not have had entrée into the world of the Soviet intelligentsia. Carl was only thirty-one and quite unknown to scholars in Russia at that time; I was twenty-five and a graduate 


\section{xii Brodsky Among $U s$}

student writing a dissertation on Bulgakov. We had only one advantage, but it was a remarkable one: we carried with us a letter of introduction from the scholar Clarence Brown to Nadezhda Yakovlevna Mandelstam, the famed memoirist and widow of the great poet Osip Mandelstam. It was thanks to her that we entered the Russian intellectual world. It was she who made the call to Elena Sergeevna Bulgakova, so that I might interview her. This, in turn, led to many other meetings with people of the literary world.

After a few meetings with Nadezhda Yakovlevna alone, we were invited to a soiree in her tiny apartment. She had invited interesting people, among them Lev Kopelev and Raya Orlova, true believers who had become dissidents after Khrushchev's Secret Speech. These generous and energetic people would become our close friends, despite the fact that the first time they came to the Hotel Armenia they unapologetically grabbed all the English-language books we had, saying they needed them more than we did ...

Over the years (we visited roughly once a year until 1980), the Kopelevs-as well as Inna Varlamova, Konstantin Rudnitsky, and many others-arranged for us to see virtually everyone we could have wished to meet in Russia, ranging from the famed literary scholar Mikhail Bakhtin to the working-class dissident Anatoly Marchenko. We received a fast education in current and past Russian literature of the sort no American university could provide at that time, since 
virtually no works by current writers were even on our reading lists, and at that time very little was available in translation.

These many encounters provided an education in the real history of Russia and the Soviet Union in the form of eyewitness accounts from people of all ages. The majority of ordinary people didn't seem to care; they went on with their daily lives, grateful for the subsidized utilities and the low price of bread. It didn't matter to them that they couldn't travel or watch certain movies or read anything on the forbidden books list. They complained only when they or their children came up against the system, in which there was no legal recourse for those who lacked contacts with the powerful.

The Russians who had accepted us into their lives educated us, instinctively recognizing they could do something with these two young Americans. They took extra time to teach us about their life, about their past, what they expected, and how to look at things from their point of view. I see now that what was fateful was the meeting of a certain kind of culture with a certain kind of temperament. We were young, energetic, and sensitive to the idea of liberation. And, most importantly, we were people for whom thought and action were very close. In the end we acted on our instincts. It was a great privilege to meet the people of the Moscow-Leningrad literary world, but we returned from that six-month stay with strong emotions. Russia was a nation in chains, that was no surprise-but expe- 
xiv Brodsky Among Us

riencing it was different from reading about it. We were enraged at how intelligent people were forced to live, and I would guess that the seeds of Ardis came from this rage.

After our first few visits to Russia we understood that most Westerners had no idea of the range and richness of the literature now being produced in Soviet Russia, and Carl began to think about a journal that would be devoted to the writers of the Silver Age (the early years of the twentieth century), so often neglected in our Russian studies, and the new ones who deserved translation. He called together a small group of our friends at Indiana University (virtually all of whom went on to become editors of Russian Literature Triquarterly) in the fall of 1969 and showed them his proposed table of contents for the first issue of a journal devoted to Russian literature. We were all very excited by the idea, but no one believed it was really possible-who would fund it? Who would buy it? None of us had ever been involved in publishing, and we knew nothing about it. We assumed that this project would develop in the distant future, if at all.

Ardis really began in the spring of 1971. Carl was restless and decided he needed a hobby — printing poetry on a hand press, perhaps. When he called one of the many commercial printers in Ann Arbor (where he was now teaching at the University of Michigan), he was advised to rent something called an IBM composer. 
Once he saw what this small machine could do-which included typesetting in Cyrillic-the next step was obvious: we would typeset the journal ourselves and print it in Ann Arbor, where printing was very cheap for runs of less than a thousand copies.

We thought long about the name of this possibly very ephemeral enterprise, and the name that came to us had its source in our Moscow experience of 1969.

In 1969 we were assigned living quarters in the former Hotel Armenia. I will not go into our many strange adventures in this hotel that had never hosted foreigners, I will merely say it was an ideal background for a Nabokov story.

After a few months we became desperate for something new to read in English. At the embassy the newspapers were weeks old, and the library seemed to have stopped with Robert Penn Warren. One day, a few months into this radio silence, a package arrived through the diplomatic pouch. Nabokov had instructed Playboy magazine to send Carl advance galleys of $A d a$, so that he could give a comment in the letters column when the magazine ran its excerpt from the new novel. This was mind-bending by itself, but to have the advance galleys of an as yet unpublished Nabokov novel in that charming old-fashioned room in the Hotel Armenia was beyond our wildest fantasies. Although ours was an unusually happy marriage, $A d a$ immediately caused a deep rift: we both wanted to read it at the same time. He, of course, was the Nabokov 
scholar, but I was the more addicted reader, which I felt should count. We began to steal the copy from each other in despicable ways - the phone would ring, Carl would unwisely drop the book to answer it, and I would grab the novel and run to the bathroom to read the next chapter. We gulped the novel down, virtually memorizing certain parts, and forever after Ada had a special place in our memories, tied to that hotel, that winter, and our desperate desire to read something new in English to offset the power of the Russian world we were exploring. Something to remind us, perhaps, that we came from the English language - the irony being that the novel was written by a Russian émigré.

That winter we had no idea of how intertwined our lives would become with Russia, how much her suffering and triumph would move us, how our lives would be changed by the people we were meeting, both wonderful and awful. Along with the internally free intelligentsia we also met brutal bureaucrats, charming informers, and the sadly compromised. We had an impulse to help but did not as yet know how. When it came time in 1971 for us to name the publishing house which existed only in our minds, Carl and I thought of $A d a$, which takes place in a mythical place blending features of both Russia and America, and its Ardis, a literary family estate straight out of Jane Austen by way of Tolstoy, transformed by Nabokov's own love for the estates of his Russian childhood. 
Carl believed in the absolute value of enlightenment-it had happened to him when he changed almost overnight from a basketball player who happened to study Russian into an intellectual who was committed to serious study. I searched through all the Russian art books I had for a suitable colophon and came on a carriage in a Favorsky woodcut. Pushkin had said that translation was the post horse of enlightenment, and here was the carriage ...

In an incredibly short span of time--three monthswe had a thousand copies of Russian Literature Triquarterly delivered to the garage of our small townhouse, paid for by a loan from Carl's father. Once the journal was through the press, we quickly reprinted a rare edition of Mandelstam, and the unpublished 1935 version of Bulgakov's play Zoya's Apartment in Russian, which I had been given in Moscow. Years later the books were better published in every way, but the charm of the first years was unique. When it came time to mail out the journal, friends would drop by to help us put them in envelopes-everyone sitting on the floor of the living room, eating pizza. It was hard to convey this reality to our Russian audience, which imagined something quite different. They assumed we would get rich publishing Russian literature, so it was difficult for them to accept the fact that most of the translators worked for free. In fact, Ardis would not have lasted a year without the contributions of Slavists and amateurs who worked for the love of the thing. We were a 


\section{xviii Brodsky Among Us}

small press, but we were the largest publishing house devoted to Russian literature outside of Russia, and our impact was much greater than our print runs would indicate. In America our focus was the libraries and the graduate students; in Russia it was the unknown readers who passed our books from hand to hand and even typed up copies to pass on-especially of Nabokov.

I must say a grateful word about the American support-little known to Russians-for our small press. Despite the primitive design and typesetting of our early books, reviewers for the major newspapers and journals quickly saw what we were trying to do and gave us more reviews than we could ever have expected. They knew that financially this was a mad enterprise and did what they could to help. In 1989 I was given a MacArthur grant, which kept us going for a long time. Over time Carl became very good at communicating directly with librarians-one flyer was titled "A Syllogism for Librarians"-and this was vital, because the hardbound library sales paid for the paperback editions. Sometimes we had the feeling that the librarians were making efforts to help Ardis.

When the authorities became aware that we had become publishers, things got more difficult. We were followed, our friends were interrogated by the secret police, and just possessing our books could endanger our readers. We warned everyone who dealt with us that we were of interest to the authorities, which any Russian could have guessed. This atmosphere of coercion and intimidation had the effect of making us 
defiant. We were afraid for our friends, but oddly not very much for ourselves. I suppose our sense of outrage relativized the fear.

We knew our writers, since we met virtually all the ones that were alive, but we did not know our readers outside of Moscow and Leningrad, and probably never would have met them if it had not been for the Moscow Book Fairs.

The only fair that Carl and I attended together took place in 1977, and it was a remarkable event. It began badly, with the censors trying to take all our books. Luckily I hid the Russian Lolita in a cupboard they didn't bother to search. We had to fight to get some of our books back ... Book hunger was a known feature of Russian life, but you didn't really have a measure for it until you saw people standing in line for two hours or more to get into a small booth where they had heard there might be interesting books on display. Readers from all over the Soviet Union made their way to these fairs, and some of them didn't seem like literary readers at all-and these were in a way the most interesting visitors. The intellectuals pushed over to the Nabokov titles and tried to read an entire novel standing, but the working-class/peasant sort of visitors didn't care or know about Nabokov: they went immediately to the biography of Esenin, which featured many photographs, including one never reproduced in the Soviet Union, that of Esenin after his suicide. This biography of the people's poet was in English, but everyone recognized Esenin's face on the cover. Why their reaction 
was so moving to me, I cannot say. Perhaps they knew who understood them.

Our Russian friendships led to many dramatic events, some of them described in this memoir. Ardis became an essential part of the Soviet literary world as major authors, tired of seeing their works destroyed by censorship, turned to us to publish their books. Ardis became a way station for émigré writers who came out during the 1970s, when controls on emigration were lifted for Jews - and for those who could "prove" they were Jewish.

In 1973 we had moved from the tiny townhouse to an old country club with a vast basement. Now we had room for offices, book storage, and for our many Russian guests, some of whom lived with us for months at a time.

Despite our best efforts to remain literary rather than political, we soon attracted attacks in the Soviet press. We published half in Russian (all of Nabokov and Brodsky, reprints of rare books), half in English (translations and scholarly monographs), roughly four hundred titles in all. The English translations were what made the authorities hesitate to ban us, because we were translating works by Soviet writers (Trifonov, Nagibin, Rasputin, etc.), something they very much valued; thus we were labeled a "complex phenomenon," which meant we were to be watched but not interfered with.

For ten years we had the usual problems of foreigners in the Soviet Union, but it was not until 1979 
that we were officially banned, due to the Metropol' affair. Metropol', which we published, was a journal put together by a combination of young and established writers, an attempt to make a point about the absurdity of censorship. It was not meant to be political, but its very nature marked it as such in the Soviet context. The leadership was stung by the participation of people like Aksyonov and Voznesenky, stars of Soviet literature. Almost everyone involved was punished, and we were banned from entering Russia. Even after Gorbachev I would have trouble getting into the country and through the airport guards until the early 1990s.

Carl never saw Russia again, since he was diagnosed with cancer in 1982. As he was getting radical chemotherapy at NIH he wrote a book about the women we had met who had conserved the literary documents of Russian culture, The Widows of Russia.

Russia was present at his funeral, not only in the form of Russian friends, but also in the form of letters and telegrams from strangers all over the Soviet Union who had heard about Carl from Western radio reports. I remember one telegram that came from the officially atheist Soviet Union while Carl was still conscious, but very sick: "Tell Carl Proffer," it said, "that a mass has been said for him in Leningrad." This made tears come to the agnostic Carl's eyes.

I ran Ardis from 1982 (when Carl was diagnosed and he switched to writing his memoirs, The Widows of Russia) until 2002, and during that time it had some 


\section{xxii Brodsky Among Us}

of its most important successes in English, such as the Glasnost anthology and the annotated translation of The Master and Margarita. Bulgakov, whom we also published in Russian, was the clearest example of how a small publishing house in America could influence the Soviet literary process. In the 1980s I began unwillingly to publish Bulgakov's Collected Works in Russian, because the Moscow edition appeared to be stalled by the censorship and my scholar friends told me that it was never going to come out and that I should do it. This was an unwise project financially, but I began it. The Ardis books made their way to Russia, and the critic Lakshin wrote a piece in a much-read Moscow newspaper chiding Soviet publishers for not doing Bulgakov: now, he wrote, the collected works are coming out beyond the sea. That was us, working in the Ardis basement in Ann Arbor-beyond the sea and beyond belief.

Ardis was represented at two more book fairs in Moscow, each reflecting the profound changes moving through the political system of the country. In 1987 I still had trouble getting a visa, and Robert Bernstein of Random House had to threaten a boycott by the other American publishers to force the authorities to give me a visa, days into the fair. Again books were confiscated by the censors. When I showed my credentials to the man registering the publishers, he repeated my name in shock and then pulled out a Bulgakov book and asked me to sign it. During this fair Ron Meyer and I were taken to a private room by literary secret 
policemen and threatened with prosecution for publishing Soviet authors without their permission; I answered that this was not true and that I had signed contracts to prove it. I also said that I preferred dealing with Gorbachev's people rather than Brezhnev's. This made them defensive, and they let me go.

In 1989 everything had changed, but I was still held at passport control, well after my daughter Arabella had already passed through. The passport officer was having long talks on the telephone with the authorities, and I began to be afraid that I would be sent back; but then Ross Teasley appeared, having illegally come through from the waiting room past the guards with Kalashnikovs. He lied convincingly, telling the passport officer that American journalists were waiting outside to interview me. One more call was made to the higherups, and I was then allowed to go through. During that fair in 1989 we saw a free public for the first time, and it was exhilarating and incredible.

It was an honor to publish the best Soviet Russian writers, and our work gave all of us who worked at Ardis something precious: we understood the meaning of our life, which was to play a role, however small, in publishing the missing volumes of Russia's lost library. Russian culture gave us many gifts, but none more important than our friendships with some of the most remarkable figures in the Russian intellectual world, including the subject of this memoir. It is hard to convey what is in my heart as I write about all of this: there really is too much to say. 
